\title{
A novel prognostic marker in severe traumatic brain injury patients: $\mathrm{pBtO} 2 / \mathrm{paO} 2$ ratio
}

\author{
R Badenes ${ }^{1 *}$, A Lozano $^{2}$, F Bilotta ${ }^{3}$, A Cueva ${ }^{4}$, B Ortolá $^{2}$, A Maruenda $^{2}$, J Belda ${ }^{2}$ \\ From ESICM LIVES 2015 \\ Berlin, Germany. 3-7 October 2015
}

\section{Introduction}

Traumatic brain injury (TBI) is a common cause of morbidity and mortality worldwide. Neuromonitoring has evolved considerably in recent years in TBI patients. Utilization of brain tissue oxygenation (pBtO2) is an important variable in the treatment of traumatic brain injury.

\section{Objectives}

The main goal is to examine whether clinical scales (Glasgow Coma Scale (GCS), Injury Severity Score (ISS), radiographic scales based on admission computed tomography (Marshall), $\mathrm{pBtO} 2$ and $\mathrm{pBtO} 2 / \mathrm{paO} 2$ ratio are associated with clinical outcome after severe TBI.

\section{Methods}

This is a prospective observational study with institutional review board approval. Patients TBI and a Glasgow Coma Scale score $\leq 8$ were identified on admission. Glasgow Coma Scale (GCS), Injury Severity Score (ISS), radiographic scales based on admission computed tomography (Marshall), IntraCranial Pressure (ICP), pBtO2 and $\mathrm{pBtO} 2 / \mathrm{paO} 2$ during first 24 hours were recorded. Patient outcome was determined as favorable (patient had no, little, or moderate disability) or unfavorable (patient died, was in a vegetative state or had severe disability) using the Glasgow Outcome Scale by medical record review at 6 months after TBI. We considered an ordinal analysis with proportional odds methodology. A logistic regression model was used to calculate the $95 \%$ CI for the odds of unfavorable outcome.

\section{Results}

Over a 3-year period, 32 patients were entered into the study. The mean age was $37 \pm 17.4$ years, injury severity

${ }^{1}$ Hospital Clinico Universitario de Valencia, Anesthesiology and Surgical-

Trauma Intensive Care, Valencia, Spain

Full list of author information is available at the end of the article score was $27.7 \pm 10.7$, and Glasgow Coma Scale score was $5.2 \pm 3.4$. At 6 months, 7 (21.8\%) patients had died, and 20 (59.3\%) had a favorable outcome. Favorable outcome consistently demonstrated higher $\mathrm{pBtO} 2 / \mathrm{paO} 2$ ratio compared with nonsurvivors including age as a covariate $(\mathrm{p}<0.001)$. Factors associated with unfavorable outcome (univariate analysis): ISS $>50$ (OR 1.47, CI 1.22-1.68), Marshall $\geq 3$ (OR 1.88, CI 1.44-2.20), ICP > 20 (OR 2.88, CI 2.52-3.24), GCS < 5 (OR 2.11, CI 1.94-2.30), $\mathrm{PtiO} 2<20$ (OR 2.16, CI 2.05-2.27) and $\mathrm{pBtO} 2 / \mathrm{paO} 2$ ratio $<0.2(\mathrm{OR}$ 3.88, CI 3.48-4.27).

\section{Conclusions}

The first 24 hours of $\mathrm{pBtO} 2 / \mathrm{paO} 2$ ratio $<0.2$ predicts mortality and outcome. When $\mathrm{pBtO} 2 / \mathrm{paO} 2$ ratio remains below 0.2 in the first 24 hours of monitoring, mortality and unfavorable outcome is increased. This study challenges the brain oxygenation threshold of $20 \mathrm{~mm} \mathrm{Hg}$ that has been used conventionally and delineates a time for monitoring $\mathrm{pBtO} 2 / \mathrm{paO} 2$ ratio that is predictive of outcome.

\section{Authors' details}

${ }^{1}$ Hospital Clinico Universitario de Valencia, Anesthesiology and SurgicalTrauma Intensive Care, Valencia, Spain. ${ }^{2}$ Hospital Clinico Universitario de Valencia, Valencia, Spain. ${ }^{3}$ Sapienza University of Rome, Rome, Italy. ${ }^{4}$ Hospital de la Ribera, Alzira, Spain.

\section{Published: 1 October 2015}

\section{Reference}

1. Gressot LV, Chamoun RB, Patel AJ, Valadka AB, Suki D, Robertson CS, et al: Predictors of outcome in civilians with gunshot wounds to the head upon presentation. J Neurosurg 2014, 121:645-652.

doi:10.1186/2197-425X-3-S1-A487

Cite this article as: Badenes et al:: A novel prognostic marker in severe traumatic brain injury patients: $\mathrm{pBtO} 2 / \mathrm{paO} 2$ ratio. Intensive Care Medicine Experimental 2015 3(Suppl 1):A487.

\section{SpringerOpen ${ }^{\circ}$}

(c) 2015 Badenes et al.; This is an Open Access article distributed under the terms of the Creative Commons Attribution License (http:// creativecommons.org/licenses/by/4.0), which permits unrestricted use, distribution, and reproduction in any medium, provided the original work is properly cited. 